C2017, Elsevier. Licensed under the Creative Commons Attribution-NonCommercialNoDerivatives 4.0 International http://creativecommons.org/about/downloads

(9) $\odot \Theta \Theta$ 


\title{
Do publicly backed venture capital investments promote innovation? Differences between privately and publicly backed funds in the UK Venture Capital Market
}

\begin{abstract}
This paper examines the link between publicly backed venture capital funds and business innovation in the UK venture capital market. In examining this relationship, the research empirically analyses the characteristics of 4,113 investment deals made to 2,359 UK based companies. We use patents as a proxy for innovation and find that obtaining investment solely from publicly backed VC funds, reduces the probability of the recipient company to apply for a patent compared with those companies that receive investments from private VC funds. In contrast, the probability of a company to have a patent or have applied for one does not vary significantly between companies that receive investments from both the public and the private sector and those companies that receive investments solely from private VC funds. The results have implications for both policy makers and practitioners and stress the importance of co-investments between publicly backed and private venture capital funds to promote innovation.
\end{abstract}

Key words: venture capital; innovation; public policy, early stage finance; economic development. 


\section{Introduction}

A substantial amount of academic research has been put into the question of the impact of venture capital in the innovation performance of a company (Gompers and Lerner, 2001; Arqué-Castells, 2012; Popov and Roosenboom, 2012). A number of studies have shown that venture-backed firms are responsible for a disproportionate number of patents (which is used as a proxy for innovation) and new technologies, and bring more radical innovations to the market faster than lower growth businesses that rely on other types of finance (see, for example: Kortum and Lerner, 2000; Hellmann and Puri, 2000, 2002; Hall and Lerner, 2010). In fact, research has shown that venture capital has played an important role in the development of some of the most significant scientific inventions and industries of our times (such as personal computers, cellular communications, microcomputer software, biotechnology, and overnight delivery) and high-growth venture-backed firms are also more likely to generate new industries (Bygrave and Timmons, 1992; Timmons and Spinelli, 2003).

Furthermore, the significant impact of venture capital on innovation has long been recognised by policy makers. Government schemes in support of the VC industry are intended to improve business innovation and growth, and close potential funding gaps, particularly for small high-technology start-ups (Sunley et al., 2005) or in particular regions (Mason and Harrison,2002). Such government-backed schemes ${ }^{1}$ aimed in leveraging private money (Sunley et al., 2005; Lerner, 2002), stimulating regional entrepreneurial activity (Mason and Harrison, 1999b) and generating R\&D spill overs (Lerner, 2002). To this end, governments around the world have taken a strong interest in facilitating access to finance for innovative high-growth companies and several schemes in support of the venture capital industry have been set up to overcome funding gaps (Sunley et al., 2005). The attempts to stimulate the supply of new sources of finance have followed different approaches, from ensuring that each region has access to regional-based $\mathrm{VC}$ funds to trying to demonstrate that investors in early stage funds can make robust returns, thereby promoting the private sector venture capital industry (Mason and Harrison, 2003).

\footnotetext{
${ }^{1}$ Public venture capital initiates are defined as ' programs that make equity or equity-like investments in young firms, or encourage other intermediaries to make such investments"' (Lerner, 2002, p. 2).
} 
Successive UK Governments have introduced several schemes in support of venture capital finance including the, Early Growth Funds (EGFs), Regional Venture Capital Funds (RVCFs), University Challenge Seed Funds (UCSFs) and the Enterprise Capital Funds (ECFs). Various evaluations of the Government venture capital schemes have highlighted that UK publicly backed funds have had a negative financial performance and their overall Internal Rate of Return (IRR) was substantial lower than the IRR reported by private funds (NAO 2009). Furthermore, such funds have had only a marginal impact on business performance (Nightingale et al., 2009). Buzzacchi et al. (2013) also found that higher public stakes are significantly correlated with a lower incidence of write-offs and a longer duration for their investments. Nevertheless, public interventions have significantly increased the supply of finance for business seeking equity finance, and the public sector has become considerably more important as an investor in both absolute and relative terms (Mason and Pierrakis, 2013).

Despite their increasing importance and attention by both academics and policy makers, little is still known about the impact of publicly backed venture capital funds on innovation. Some of the most informative studies are the ones by Kortum and Lerner (2000) and Brander et al. (2014). Kortum and Lerner (2000) measured the role of VC in innovation using patents as a proxy variable for business innovation while Brander et al. (2014) expanded the existing literature on the relationship between venture capital and patenting by including an additional parameter in this relationship, which is the source of venture capital (public or private). In particular, the latter study provides strong evidence on the role of government VC in stimulating innovation. Additionally, it showed that enterprises with moderate government venture capital support outperform enterprises with only private venture capital support and those with extensive government venture capital support, both in terms of value creation and patent creation. Another study by Bertoni and Tykvová (2015) explored whether governmental venture capital investors (GVCs) spur invention and innovation in young biotech companies in Europe and found that GVCs, as stand along investors, have no impact on invention and innovation but boost the impact of independent venture capital investors (IVCs) when they invest together. Based on these theoretical premises, this research investigates the likely impact of the UK based publicly backed venture capital funds on business innovation. 
In this paper we attempt to shed more light on the government backed venture capital funds (GVCs) and business innovation nexus by using a combination of commercial databases and publicly available information. This allows us to construct a unique database of 4,113 individual investments and observe several characteristics of the VC backed companies such as amounts received, funding source, funding rounds and patent grants or applications. Importantly, we are able to distinguish between private and government backed venture capital investments and capture potential industrial and geographical differences. Hence, our work goes beyond the existing literature by analysing the relation between government backed venture capital investments and innovation using a much larger sample of UK based companies $^{2}$, focusing on the regional heterogeneity of the UK market. In this way, it reveals new characteristics of the venture capital communities in the UK and contributes to the debate about the potential impact of VC in economic development and innovation proxied by patents.

The remainder of the paper is structured as follows: Section 2 provides a background of the study and derives the hypotheses. Section 3 describes the data. In section 4 the empirical findings are discussed. Finally, section 5 provides concluding remarks and further research directions.

\section{Literature review and hypothesis development}

\subsection{Patents and venture capital}

A large body of literature suggests that venture capital plays a central role in the emergence of new industries by funding and supporting innovative companies which later dominate these industries. Indeed, Lerner and Watson (2008) argue that the venture capital model is more effective in commercialising scientific discoveries than the corporate sector, despite the latter's large expenditure on R\&D. Venture capital investment speeds the development of companies, enabling them to transform ideas quickly into marketable products and become industry leaders through first mover advantages (Zhang, 2007). Against this interpretation of the results found in the literature cited above is the work of Hirukawa and Ueda (2011) which argued that this is one-sided interpretation and there may be an opposite causality: arrivals of

\footnotetext{
${ }^{2}$ Brander et al. (2010) used the number of investments made to 60 UK publicly backed companies while this research uses a much larger sample of 1,467 publicly backed investments.
} 
significant innovation opportunities stimulate new firm start-ups to exploit such opportunities and these start-ups demand VC because venture capitalists are complements to such firms that VC spurs growth and innovation of new firms.

In fact, there are two distinctive streams of literature dealing with the relationships between venture capital and patents, namely on the role of patents as driver of $\mathrm{VC}$ investments (Kortum and Lerner, 2000; Kaplan et al., 2009; Haeussler et al., 2009; Hirukawa and Ueda, 2011) and on the impact of VC investments in stimulating patent creation (Kortum and Lerner, 2000; Gompers and Lerner, 2001; Lerner and Watson, 2008). Our paper contributes to the latter body of literature by examining the role of publicly backed venture capital investments in patent creation.

Looking at the relationship between venture capital and the number of patents, a variety of studies suggest that venture-backed firms are responsible for a disproportionate number of patents and new technologies (Kortum and Lerner 2000), and they seem to bring more radical innovations to market faster than lower growth businesses that rely on other types of finance (Gompers and Lerner, 2001). More particularly, Kortum and Lerner (2000) examined the influence of venture capital on patented inventions in the United States across twenty industries over three decades. They found that increases in venture capital activity in an industry are associated with significantly higher patenting rates. While the ratio of venture capital to R\&D averaged less than 3 percent from 1983-92, they estimated that venture capital may have accounted for 8 percent of industrial innovations in that period. The strong relationship between venture capital and patenting on an industry level is also indicative of a relationship between venture disbursements and innovative output.

Mann and Sager (2007) have analysed the relation between the patenting behaviour of start-up firms and the progress of those firms through the venture capital cycle. Linking the data relating to venture capital financing of software start-up firms with data concerning the patents obtained by those firms, they found a significant and robust positive correlation between patenting practices and several variables measuring the firm's performance (including number of rounds, total investment, exit status, receipt of late stage financing and longevity).

Moreover, Hellmann and Puri (2000) find a strong association between patents and VC funding. Therefore, the basic theoretical premise of this paper is that there is a strong 
relationship between venture capital and patent creation. Building on this premise, we hypothesise that:

Hypothesis 1: Follow up venture capital investments are positively associated with patents.

\subsection{Public and private VC funds}

It is often argued that the value added by experienced venture capital rests not only in its 'hard' financing aspects but also in 'soft' advice and knowledge roles (Kaplan and Stromberg, 2001; Pinch and Sunley, 2009; Hall and Lerner, 2010; Luukkonen et al., 2013). Knowledge regarding the target company's industry allows the venture capitalist to oversee investments more efficiently and more effectively, in part because industry experience enhances the venture capitalist's ability to recognize signs of trouble at an early stage (Sonerson and Stuart, 2001). Venture capitalists provide several critical services in addition to providing money such as helping the company to raise more money, reviewing and helping to formulate business strategy, filling in the management team, and introducing the company to potential customers and suppliers (Gorman and Sahlman, 1989).

The competence of the venture capitalist investment managers arises from active business involvement in the respective industry. It cannot be acquired in short order, nor is it easily transferable (Kanniainen and Keuschnigg, 2004). Gompers and Lerner (1999, p. 4) note that: "Not only is it difficult to raise a new venture capital fund without a track record, but the skills needed for successful venture capital investing are difficult and time-consuming to acquire". This has direct implications to the creation and management of the government backed funds. Despite their commitment to act as commercial funds, various scholar (Mason and Harrison, 2003; Kanniainen and Keuschnigg, 2004; Shäfer and Shilder, 2009) found to be a lack of venture-capital skills to enable effective fund management. Knockaert et al. (2006) find that investment managers of government backed funds are less involved in valueadding activities than other investors, while Luukkonen et al. (2013) argue that the contributions of private $\mathrm{VC}$ funds are significantly higher than those of GVC funds in a number of areas, including the development of the business idea, professionalisation and exit orientation. In the same way Shäfer and Shilder (2009) using German data suggest that public sector venture capital funds may not be as 'smart' as private sector venture capital in terms of 
adding value. The capabilities of public sector fund managers are therefore often questioned, both in terms of their ability to make good investments (quality of deal flow, domain knowledge, effectiveness of their due diligence) and to add value to their investee companies (e.g. mentoring skills, strategic insights, networks) (see NESTA, 2009). According to Munary and Toschi (2009), even if the public intervention was target to companies with a real need for governmental sustain, this financial support could be inefficiently managed by local VCs due to their lack of experience and skills.

Unlike Private VC investors (PVCs) who are generally interested in maximising their capital gains by increasing the market value of their new venture investees, GVC investors have much broader objectives. A patent adds value to the company and therefore we hypothesise that:

Hypothesis 2: PVCs have a stronger impact on patent creation than GPVs.

We further argue that publicly backed VCs and private VCs are complements in their contribution to innovation. To pursue innovation activities including patenting, companies need to have a long-term strategy towards innovation and access to a rich set of resources and added value capabilities. Similarly to Bertoni and Tykvová (2015), we argue that this is the case when a company is invested by both a publicly backed VC fund and a private VC fund. Publicly backed and private funds have access to different networks of contacts, have different skills and experience and support differently their portfolio companies (Luukkonen et al., 2013). On one hand, publicly backed funds have a wider outreach and are better connected with the regional innovation players such as university labs, university incubators and science parks than the private venture capital funds. On the other hand, private VC funds have access to more financial resources and add more value to the portfolio companies (Shäfer and Shilder, 2009; Luukkonen et al., 2013). Accordingly, we expect to observe more patenting activity in companies where publicly backed VCs and private VCs co-invest than in companies with only one investor type.

Hypothesis 3: GVC funds are more likely to invest in companies with patents when they coinvest together with PVC funds.

Finally, there are two important aspects of VC activity that need to be distinguished, selection and nurturing, or the ability of the investment managers to select good ventures and 
the ability of the managers to nurture these ventures (see Baumand Silverman, 2004). Based on the lack of appropriate skills identified in the literature, it is believed that venture capitalists from the public sector will not be able to provide post-investment support of similar quality to the support provided by their private counterparts. Therefore, while they may be able to select good opportunities, perhaps due to their wide network of contacts in regional Universities, incubators and science parks, they may be less capable of nurturing their portfolio companies. Therefore, we hypothesise that:

Hypothesis 4: PVC funded companies will have greater pre-investment (before any VC funding) innovation capabilities (patents) as compared to companies funded solely by GVC funds.

Once invested, GVC investors may often pursue broader strategic objectives for their new venture investments (rather than getting patents and consequently gaining value). PVC investors are also better skilled than GVC investors (Kanniainen and Keuschnigg, 2004). Therefore the final hypothesis of this paper argues that:

Hypothesis 5: PVC funded companies will exhibit greater post-investment (after $1^{\text {st }}$ investment is made) rates of innovation as compared to companies funded solely by GVC funds.

\section{Data and research methodology}

\subsection{Data collection strategy}

In order to probe beyond the British Venture Capital Association (BVCA) aggregate figures, the Library House data (now absorbed into Dow Jones Venture Source) has been utilised in this paper. The Library House database reports individual investments along with various additional information on the investor and business which enabled customised tables to be generated. This includes: deal size (in British Pounds), number of funding round, industry operation and region where the fund recipient company is based. The availability of such information on individual deals allows considerable flexibility in analysis. Using Library House database, a dataset of 4,113 individual investments to 2,359 UK based companies 
spread to all UK regions for the period 2000-2008 was created. The period covered in the analysis, 2000-2008 was determined by data availability during the data collection period. The information provided by Library House and extensive desk research has allowed for the classification of investments into the following categories (for description of the variables see Table A1 in appendix):

(i) PVCs: Deals involving one or more private sector investors. This category captures solely deals made by private funds and without the involvement of one or more publicly backed venture capital firms.

(ii) GVCs: Deals involving one or more publicly backed funds (for example, RVCFs). Government backed funds are funds that have received some or all of their capital from the public sector, including regional development agencies, the European Union, devolved administrations or government schemes. They are normally managed by independent fund managers. The dataset does not allow us to differentiate between publicly backed funds and those solely supported and run by the public sector. As an example, investments made by the Scottish Co-Investment Fund, Scottish Seed Fund, Scottish Venture Fund, and Business Growth Fund are not separately identified but simply classified as 'Scottish Enterprise' in the dataset. The data from all these publicly backed funds are aggregated in order to conduct the analysis using a sufficient number of cases. While separate programmes, their similarities in terms of stage of investment financed, fund structures used and sought outcomes are sufficiently common to allow such an aggregation (for an analysis see Nightingale et al., 2011).

(iii) GVCs and PVCs Co-investments: Deals - which are termed here co-investments - in which one or more private sector investors has invested alongside one or more public sector funds. Investments in this category include both ad-hoc syndications between public sector funds and private investors and also investments involving Co-Investment Funds that have been established specifically to invest alongside private investors.

\subsubsection{Patents as a proxy of innovation}

Patents, number of applications or grants, and business R\&D expenditure have been widely used by scholars as proxies of innovation (see Mann and Sager, 2007; Ueda and Hirukawa, 2006). Both proxies are widely available at industry or country level and partially available at the regional level. However, we recognise that both of these measurements of innovations 
have important limitations. According to Frenz and Oughton (2005), there are three main weaknesses of patent data. Firstly, patents do not capture innovation by firms that are Schumpeterian imitators, that is, firms that introduce products or processes that are new to their firm but not new to the market or industry. Secondly, not all innovations that are new to the market are patented. Thirdly, the propensity to patent may vary significantly across industries and sectors, for example, between manufacturing and services. Moreover, patents are often registered at the Head Office of an enterprise, thus there are regional distortions that arise as a result of administrative features of the patent system (Smith, 2005). In addition, patents are not always introduced on the market and their economic value can be questionable (Jaffe and Lerner, 2004). Verdolini and Galeotti (2009) argue that patent data cannot provide any insight on, what they call, disembodied technological change, such as for example the learning process by which individuals can increase the productivity of the production process thanks to "learning by doing", is clearly left out of a study based on patent data.

Keeping in mind the limitations outlined above, and the absence of a more suitable and easily identifiable measurement for innovation for the purpose of this research, the use of patent data with the purpose of investigating the relationship between $\mathrm{VC}$ and innovation has several advantages and as Grilliges puts it: "after all, patent does represent a minimal quantum of invention that has passed both the scrutiny of the patent office as to its novelty and the test of the investment of effort and resources by the inventor and his organization into the development of this product or idea, indicating thereby the presence of a non-negligible expectation as to its ultimate utility and marketability" (Grilliches, 1998, p.296). A patent application may suggest that the business has the potential to get a patent. In addition, a patent application is the preferred proxy for our research, since there might be a significant time lag between filing an application and receiving a grant (Hall et al. 2001) and the application date is more indicative of when the knowledge is created (Chung and Yeaple, 2008).

Using the EPO online search facility which is integrated in the UK Patents Office website, it was possible to identify individual companies that have been granted or have applied for an EPO patent. Matching the Library House database with the EPO database, it was possible to check which of the 2,359 companies that received one or more of the 4,113 individual VC investments had received or applied for a patent at the time of the investment. As an example, a company from our dataset had 2 patents when it received its first 
investment, 6 patents when it received its second investment, 9 when it received its third investment and 10 when it received its fourth round of investment.

\subsection{Sample characteristics}

The investments are presented by source of finance and are broken down into four categories: All investments, Government VC investments (GVCs), Private VC investments (PVCs) and GVCs \& PVCs co-investments (see Table 1). Data on the size (amounts) of the individual investments were not always available. In Table 2 we present correlations between industry sectors and number of patents, investment deals, size of investment deals and financing rounds.

As shown in Table 2 several industries are closely correlated with patents. For instance, the correlation coefficient of 0.22 between ICT and patents and 0.22 between Pharmaceutical \& Biotechnology and patents, implies that VC backed companies that operate in these two sectors are more likely to seek patent protection compared with other sectors. In contrast, companies operating in Software \& Computer Services, Consumer \& Business and Media are less likely to have a patent. The stage of investment (number of round) is also positively correlated with patent (0.23) reflecting the relationship between patent and later stage deals as examined earlier. Interestingly, investments made by GVCs are negatively correlated with patents and this relationship will be examined further in the next sections. 
Table 1: Descriptive statistics

\begin{tabular}{|c|c|c|c|c|c|c|c|c|c|c|c|}
\hline & \multicolumn{5}{|c|}{ All deals } & & \multicolumn{5}{|c|}{ GVCs } \\
\hline & $\mathrm{N}$ & Mean & Std. Dev. & Min & Max & & $\mathrm{N}$ & Mean & Std. Dev. & Min & Max \\
\hline Year & 4113 & 2004 & 2.432 & 2000 & 2008 & Year & 652 & 2005 & 2.174 & 2000 & 2008 \\
\hline Amounts* & 3173 & 1.331 & 1.097 & 0.063 & 7.745 & Amounts* & 473 & 0.491 & 0.291 & 0.063 & 2.746 \\
\hline Rounds & 4113 & 1.85 & 1.206 & 1 & 10 & Rounds & 652 & 1.466 & 0.877 & 1 & 7 \\
\hline \multirow[t]{3}{*}{ Patents } & 4113 & 4.01 & 13.189 & 0 & 319 & Patents & 652 & 1.628 & 6.376 & 0 & 98 \\
\hline & \multicolumn{5}{|c|}{ PVCs } & & \multicolumn{5}{|c|}{ GVCs \& PVCs Co-investments } \\
\hline & $\mathrm{N}$ & Mean & Std. Dev. & Min & Max & & $\mathrm{N}$ & Mean & Std. Dev. & Min & Max \\
\hline Year & 2645 & 2004 & 2.525 & 2000 & 2008 & Year & 816 & 2005 & 1.948 & 2000 & 2008 \\
\hline Amounts* & 2075 & 1.658 & 1.186 & 0.071 & 7.745 & Amounts* & 625 & 0.882 & 0.545 & 0.071 & 4.647 \\
\hline Rounds & 2645 & 1.926 & 1.239 & 1 & 10 & Rounds & 816 & 1.919 & 1.263 & 1 & 9 \\
\hline Patents & 2645 & 4.851 & 15.587 & 0 & 319 & Patents & 816 & 3.213 & 7.013 & 0 & 51 \\
\hline
\end{tabular}

* Square root of the amount of each deal divided by 1000 
Table 2: Correlations between deal characteristics and industry

\begin{tabular}{|c|c|c|c|c|c|c|}
\hline Variables & Patents & PVCs & $\begin{array}{l}\text { GVCs \& } \\
\text { PVCs Co- } \\
\text { investments }\end{array}$ & GVCs & $\begin{array}{l}\text { Size of } \\
\text { deal }\end{array}$ & $\begin{array}{l}\text { Number } \\
\text { of round }\end{array}$ \\
\hline Patents & 1 & & & & & \\
\hline $\begin{array}{l}\text { PVCs } \\
\text { GVCs \& PVCs Co- } \\
\text { investments }\end{array}$ & $\begin{array}{l}0.01 \\
0.06\end{array}$ & $\begin{array}{c}1 \\
\mathbf{- 0 . 6 4}\end{array}$ & 1 & & & \\
\hline GVCs & -0.13 & -0.56 & -0.21 & 1 & & \\
\hline Size of deal & 0.07 & 0.29 & -0.17 & -0.20 & 1 & \\
\hline Number of round & 0.23 & 0.05 & 0.03 & -0.14 & 0.12 & 1 \\
\hline Consumer \& Business & -0.19 & -0.02 & 0.00 & 0.04 & -0.01 & -0.11 \\
\hline Energy & 0.07 & 0.02 & 0.00 & -0.03 & 0.04 & -0.01 \\
\hline Finance & -0.07 & 0.07 & -0.04 & -0.05 & 0.15 & -0.06 \\
\hline Healthcare & 0.07 & -0.07 & 0.07 & 0.01 & -0.06 & 0.02 \\
\hline ICT & 0.22 & -0.01 & 0.02 & -0.03 & 0.03 & 0.15 \\
\hline $\begin{array}{l}\text { Leisure Goods } \\
\text { Manufacturing \& } \\
\text { Industrial }\end{array}$ & $\begin{array}{l}-0.04 \\
0.06\end{array}$ & $\begin{array}{l}-0.02 \\
\mathbf{- 0 . 0 7}\end{array}$ & $\begin{array}{l}-0.01 \\
\mathbf{0 . 0 4}\end{array}$ & 0.06 & $\begin{array}{r}0.06 \\
\mathbf{- 0 . 0 9}\end{array}$ & $\begin{array}{l}-0.03 \\
-0.04\end{array}$ \\
\hline $\begin{array}{l}\text { Media } \\
\text { Pharmaceuticals \& } \\
\text { Biotechnology } \\
\text { Software \& Computer } \\
\text { Services }\end{array}$ & $\begin{array}{r}0.22 \\
-0.21\end{array}$ & $\begin{array}{l}-0.05 \\
\mathbf{0 . 0 9}\end{array}$ & $\begin{array}{l}\mathbf{- 0 . 0 4} \\
0.01 \\
\mathbf{- 0 . 0 6}\end{array}$ & $\begin{array}{r}0.00 \\
\mathbf{- 0 . 0 4}\end{array}$ & $\begin{array}{r}0.07 \\
-\mathbf{0 . 0 3}\end{array}$ & $\begin{array}{l}-0.08 \\
0.08 \\
-0.04\end{array}$ \\
\hline
\end{tabular}

Notes: * Correlation coefficients that are statistically significant at $10 \%$ level are in bold.

A venture capital backed company normally receives several rounds of finance called funding rounds. Each time a company needs new finance (for example in order to launch a new product, to conduct new trails etc.) it raises a new round (see Gompers, 1995). This happens until the company is ready to exit through an IPO or a Merger or Acquisition. Some companies need only few rounds before exit while others need several. Companies that are not able to raise further funding rounds are normally acquired or cease operations. A venture capital fund may take part in one or several funding rounds. Because the structure of venture capital financing gives venture capitalists a realistic opportunity to terminate firms after each round, and makes each additional round a substantial indicator of progress, the number of rounds is also a good proxy for performance (Gompers and Lerner, 2001; Mann and Sager, 2007). Table 3 presents the association between VC backed companies and patents or patent applications at each funding round. We also test whether or not there is a difference between the means and the results are reported in Table A2 in appendix. 
Table 3: VC investment made to companies

\begin{tabular}{lcccccccc}
\hline & \multicolumn{2}{c}{ All deals } & \multicolumn{2}{c}{ PVCs } & \multicolumn{2}{c}{ GVCs } & \multicolumn{2}{c}{$\begin{array}{c}\text { GVCs \& PVCs } \\
\text { Co-invest. deals }\end{array}$} \\
\hline 1 & 2 & 3 & 4 & 5 & 6 & 7 & 8 & 9 \\
\hline Variable & Obs. & $\begin{array}{c}\text { Patents } \\
\text { Mean } \\
\text { (dummy) }\end{array}$ & Obs. & $\begin{array}{c}\text { Patents } \\
\text { Mean } \\
\text { (dummy) }\end{array}$ & Obs. & $\begin{array}{c}\text { Patents } \\
\text { Mean } \\
\text { (dummy) }\end{array}$ & $\begin{array}{c}\text { Obs. } \\
\text { Patents } \\
\text { Mean } \\
\text { (dummy) }\end{array}$ \\
\hline Funding round 1 & 2184 & 0.12 & 1319 & 0.12 & 451 & 0.08 & 414 & 0.16 \\
Funding round 2 & 1035 & 0.25 & 687 & 0.25 & 137 & 0.15 & 211 & 0.3 \\
Funding round 3 & 498 & 0.4 & 357 & 0.41 & 39 & 0.26 & 102 & 0.43 \\
Funding round 4 & 228 & 0.43 & 165 & 0.46 & 13 & 0.31 & 50 & 0.38 \\
Funding round 5 & 107 & 0.42 & 79 & 0.46 & 6 & 0.33 & 22 & 0.32 \\
Funding round 6 & 34 & 0.44 & 20 & 0.45 & 5 & 0.25 & 11 & 0.5 \\
Funding round 7 & 15 & 0.47 & 12 & 0.64 & 1 & 0 & 3 & 0 \\
Funding round 8 & 9 & 0.56 & 6 & 0.67 & & & 3 & 0.33 \\
\hline Total & 4113 & & 2645 & & 652 & & 816 & 0.32 \\
\hline
\end{tabular}

Notes: Column (1) of Table 3 includes funding rounds from one to ten. Columns (2), (4), (6) and (8) include the number of investments by round, while columns (3), (5), (7) and (9) shows the proportion of investments that were made to companies that had applied for a patent at the time of investment.

Around 12 percent of all first round investments (GVCs or PVCs) are found to be associated with a patent or patent application. From the 1,035 investments in round 2, one quarter (25 percent) are associated with one or more patent applications at the time of investment. In later funding rounds the proportion of investments associated with patents exceeds 40 percent. It is clear that the percentage of investments that is associated with patents rises as the funding of the company progresses to later rounds. As a result hypothesis $\mathbf{1}$ is supported suggesting that follow up venture capital investments are positively associated with patents. However, we recognise that this finding is open to criticism: For example it can be argued that companies are more likely to progress to the next level of funding if they have a patent or companies acquire patents during their investments journey. This issue will be further explored later in the paper.

Furthermore, Table 3 shows that patents granted or patent applications are stronger related to PVCs than GVCs. Specifically, 12 percent of all first round PVC investments, 8 percent of GVC investments and 16 percent of GVC \& PVC co-investments are made to companies that undertake patent protection. As the investment journey progresses, the proportion of GVC backed companies with patent applications increases but to a lower rate compared with PVC backed companies. This provides some preliminary evidence to support hypothesis 2 of this research. 


\section{Empirical findings}

Turning to our empirical specification, a negative binominal probit model (see Cameron and Trivedi, 1998) is used to examine the relationship between the type of venture capital investment (GVC, PVC or co-investment between the two) and the innovation outputs of the firm (proxied by patent applications). In this case the dependent variable indicates the number of patent applications of the company at each funding round. Negative binomial regression is preferred for (nonnegative) over-dispersed count outcome variables (i.e. a likelihood ratio test comparing this model to a Poisson model was estimated suggesting that the negative binomial model is more appropriate than the Poisson model). However, we also estimate ordered probit and poisson regression models as a reference and robustness check, but the results are similar and thus are not discussed here for reasons of brevity.

Since individual firm operates in a sector, which might have similar characteristics, we consider sector heterogeneity in the specification to allow for a degree of dependency within sectors. Regional dummies are also included in the model to take into account regional variations. Finally, we incorporate clustering to allow the analysis to deal with potential unobserved individual effects as well as the extent of the inconsistency in the random estimates when the individual effect and some of the regressors are correlated (AmuedoDorantes and Kimmel, 2005). 
Table 4: Modelling the number of patents creation using a negative binomial model ${ }^{1}$

\begin{tabular}{|c|c|c|c|c|c|c|c|c|c|c|}
\hline & $\mathrm{dy} / \mathrm{dx}$ & $\begin{array}{l}\text { Delta- } \\
\text { method } \\
\text { Std. Err. }\end{array}$ & $\mathrm{dy} / \mathrm{dx}$ & $\begin{array}{l}\text { Delta- } \\
\text { method } \\
\text { Std. Err. }\end{array}$ & $\mathrm{dy} / \mathrm{dx}$ & $\begin{array}{c}\text { Delta- } \\
\text { method } \\
\text { Std. Err. }\end{array}$ & $\mathrm{dy} / \mathrm{dx}$ & $\begin{array}{l}\text { Delta- } \\
\text { method } \\
\text { Std. Err. }\end{array}$ & Coef. & $\begin{array}{c}\text { Delta- } \\
\text { method } \\
\text { Std. Err. }\end{array}$ \\
\hline Public investment & $-0.469 * * *$ & 0.065 & $-0.300 * * *$ & 0.063 & $-0.200 * * *$ & 0.057 & $-0.147 * *$ & 0.071 & $-0.115 * *$ & 0.045 \\
\hline $\begin{array}{l}\text { Co-investment } \\
\text { Number of }\end{array}$ & -0.038 & 0.048 & $-0.109 * *$ & 0.048 & -0.062 & 0.043 & -0.016 & 0.052 & -0.038 & 0.036 \\
\hline investors & - & - & $0.13 * * *$ & 0.014 & $0.097 * * *$ & 0.013 & $0.082 * * *$ & 0.017 & $0.023 * *$ & 0.012 \\
\hline Number of round & - & - & - & - & $0.155^{* * *}$ & 0.014 & $0.143 * * *$ & 0.016 & $0.065 * * *$ & 0.012 \\
\hline Deal size & - & - & - & - & - & - & $0.072 * * *$ & 0.020 & $0.062 * * *$ & 0.016 \\
\hline $\begin{array}{l}\text { Industry dummies } \\
\text { Regional }\end{array}$ & - & - & - & - & - & - & - & - & \multicolumn{2}{|c|}{ YES } \\
\hline dummies & - & - & - & - & - & - & - & - & \multicolumn{2}{|c|}{ YES } \\
\hline Year dummies & - & - & - & - & - & - & - & - & \multicolumn{2}{|c|}{ YES } \\
\hline Log-Likelihood & \multicolumn{2}{|c|}{$-3,546.175$} & \multicolumn{2}{|c|}{$-3,496.306$} & \multicolumn{2}{|c|}{$-3,414.550$} & \multicolumn{2}{|c|}{$-2,748.704$} & \multicolumn{2}{|c|}{$-2,374.548$} \\
\hline LR test of $\alpha=0$ & $\operatorname{chi} 2(1)=$ & $35.470 * * *$ & $\operatorname{chi} 2(1)=$ & $57.930 * * *$ & $\operatorname{chi} 2(1)=$ & $19.390 * * *$ & $\operatorname{chi} 2(1)=$ & $878.960 * * *$ & $\operatorname{chi} 2(1)=$ & $427.760 * * *$ \\
\hline $\mathrm{BIC}$ & \multicolumn{2}{|c|}{$-27,102.370$} & \multicolumn{2}{|c|}{$-27,128.547$} & \multicolumn{2}{|c|}{$-27,283.739$} & \multicolumn{2}{|c|}{$-19,937.667$} & \multicolumn{2}{|c|}{$-18,406.834$} \\
\hline Observations & \multicolumn{2}{|c|}{4,113} & \multicolumn{2}{|c|}{4,106} & \multicolumn{2}{|c|}{4,106} & \multicolumn{2}{|c|}{3,163} & \multicolumn{2}{|c|}{2,936} \\
\hline
\end{tabular}

Notes:
$* * * \mathrm{p}<0.01, * * \mathrm{p}<0.05, * \mathrm{p}<0.1$
Standard errors adjusted for cluster

Standard errors adjusted for cluster effects.

${ }^{1}$ Ordered probit and poisson regression models provide similar information. 
In Table 4 we present the results from the estimations (marginal effects). Overall, the results in Table 4 suggest that GVCs standalone investments are strongly and negatively associated with the number of patent applications. Specifically, after controlling for other variables, on average public investments have 0.115 fewer patents than private investments. In addition, obtaining GVCs \& PVCs Co-investments is not associated with an increase or a decrease in the likelihood of the company to patent an idea compared with those that receive investment from PVCs funds. Hence hypothesis $\mathbf{2}$ is supported while hypothesis $\mathbf{3}$ is not. In other words, companies that receive investments from private venture capital funds are more likely to apply for more patents compared with those companies that receive investments from government backed venture capital funds only.

In order to control for the selection or nurturing effect, all the investments have been partitioned into first round investments (2184 in total). By checking the date the company had applied for a patent, we were able to identify that 264 companies had a patent at the time of the $1^{\text {st }}$ round of investment, leaving 1920 companies without patent at the time. We then examine whether any of these 1920 companies applied for a patent after the $1^{\text {st }}$ investment and we find that 310 of them applied. This sample allows us to observe whether the company had applied for a patent at the time of its first investment, and whether the company applied for a patent after the first investment was made. We use three distinctive models for this analysis: Bivariate Probit (columns 1 and 2), Multivariate Probit (columns 3 and 4) and finally Probit with Sample Selection (Heckman Probit), (columns 5 and 6). The first two models permit the two dependent variables to depend on the same list of independent variables allowing for a correlation between the error terms of the two equations (see Cappellari and Jenkins, 2003; Greene, 2003). Indeed the coefficient of correlation between the two error terms $(\rho)$ is found to be statistically different from zero. The last model assumes that we observe whether the company applied for a patent after the first investment only if the firm had applied for a patent at the first time of its investment (see Heckman, 1979). However, the LR test does not reject independence of the two errors terms suggesting that selection bias is not a problem for the model estimated.

The coefficients of these models are presented in Table 5. Columns (1), (3) and (5) examine whether the company had applied for a patent at the time it received its first investment. Table 5 shows a negative coefficient for GVCs but not statistically significant in all three models. Similarly, columns (2), (4) and (6) examine whether there was an increase in the number of patent applications of the company since it received its first investment. The 
coefficients for GVCs are negative but this time statistically significant in all three models. The results of the analyses in Table 5 suggest that the professionals from the publicly backed funds are equally capable in identifying and investing in companies with patent potential as the professionals from the private funds, but less capable in supporting companies in acquiring new patents, once the investments has been made, when they invest alone.

Therefore hypothesis $\mathbf{4}$ is rejected while hypothesis $\mathbf{5}$ is confirmed. This suggests that the problem may not be the inability of GVC fund managers to select innovative companies but their limited capacity to nurture and assist their portfolio companies in applying and consequently receiving patents. 
Table 5: Pre-funding and post-funding innovation capabilities for new ventures

\begin{tabular}{|c|c|c|c|c|c|c|c|c|c|c|c|c|}
\hline \multirow{3}{*}{$\begin{array}{l}\text { Model: } \\
\text { Variable: }\end{array}$} & \multicolumn{4}{|c|}{ Bivariate probit } & \multicolumn{4}{|c|}{ Multivariate probit } & \multicolumn{4}{|c|}{ Probit with sample selection ${ }^{1}$} \\
\hline & \multicolumn{2}{|c|}{ (1) } & \multicolumn{2}{|l|}{$(2)$} & \multicolumn{2}{|c|}{ (3) } & \multicolumn{2}{|l|}{ (4) } & \multicolumn{2}{|c|}{$(5)$} & \multicolumn{2}{|c|}{$(6)$} \\
\hline & \multicolumn{2}{|c|}{$\begin{array}{c}\text { Had a patent } \\
\text { when received } \\
\text { its } 1 \mathrm{st} \\
\text { investment } \\
\end{array}$} & \multicolumn{2}{|c|}{$\begin{array}{c}\text { There was an } \\
\text { increase in patents } \\
\text { since 1st } \\
\text { investment }\end{array}$} & \multicolumn{2}{|c|}{$\begin{array}{l}\text { Had a patent } \\
\text { when received } \\
\text { its } 1 \mathrm{st} \\
\text { investment } \\
\end{array}$} & \multicolumn{2}{|c|}{$\begin{array}{c}\text { There was an } \\
\text { increase in patents } \\
\text { since } 1 \mathrm{st} \\
\text { investment }\end{array}$} & \multicolumn{2}{|c|}{$\begin{array}{l}\text { Had a patent when } \\
\text { received its } 1 \mathrm{st} \\
\text { investment } \\
\text { (selection) }\end{array}$} & \multicolumn{2}{|c|}{$\begin{array}{l}\text { There was an increase } \\
\text { in patents since } 1 \mathrm{st} \\
\text { investment (outcome) }\end{array}$} \\
\hline GVCs & -0.079 & 0.140 & $-0.254 * *$ & 0.125 & -0.090 & 0.139 & $-0.286^{* *}$ & 0.126 & -0.066 & 0.147 & $-1.228 * * *$ & 0.442 \\
\hline GVCs \& PVCs Coinv. & 0.077 & 0.161 & 0.236 & 0.148 & 0.078 & 0.160 & $0.282 *$ & 0.151 & -0.108 & 0.173 & 0.676 & 0.487 \\
\hline Number of investors & $0.127 * *$ & 0.052 & $0.163 * * *$ & 0.046 & $0.123 * *$ & 0.051 & $0.148 * * *$ & 0.046 & $0.124 * *$ & 0.053 & -0.088 & 0.175 \\
\hline Deal size & 0.086 & 0.057 & -0.017 & 0.051 & $0.093 *$ & 0.055 & -0.011 & 0.053 & 0.071 & 0.058 & 0.287 & 0.210 \\
\hline Industry dummies & \multicolumn{2}{|c|}{ YES } & \multicolumn{2}{|c|}{ YES } & \multicolumn{2}{|c|}{ YES } & \multicolumn{2}{|c|}{ YES } & \multicolumn{2}{|c|}{ YES } & \multicolumn{2}{|c|}{ YES } \\
\hline Regional dummies & \multicolumn{2}{|c|}{ YES } & \multicolumn{2}{|c|}{ YES } & \multicolumn{2}{|c|}{ YES } & \multicolumn{2}{|c|}{ YES } & \multicolumn{2}{|c|}{ YES } & \multicolumn{2}{|c|}{ YES } \\
\hline Year dummies & \multicolumn{2}{|c|}{ YES } & \multicolumn{2}{|c|}{ YES } & \multicolumn{2}{|c|}{ YES } & \multicolumn{2}{|c|}{ YES } & \multicolumn{2}{|c|}{ YES } & \multicolumn{2}{|c|}{ YES } \\
\hline Log-Likelihood & \multicolumn{4}{|c|}{$-1,017.585$} & \multicolumn{4}{|c|}{$-1,037.193$} & & & .975 & \\
\hline Wald/LR test of $\rho=0$ & & ii $2(1)=$ & $143.272 * * *$ & & & $\mathrm{i} 2(1)=$ & $121.895^{* * *}$ & & & $\operatorname{chi} 2(1$ & $=0.120$ & \\
\hline Observations & & & 46 & & & & 46 & & (1261 c & ored obs & $\begin{array}{l}46 \\
\text { nd } 185 \text { cens }\end{array}$ & obs) \\
\hline
\end{tabular}

\section{Notes:}

$* * * \mathrm{p}<0.01, * * \mathrm{p}<0.05, * \mathrm{p}<0.1$

${ }^{1}$ The selection equation includes a proxy of the "quality of the patent" at the 1 st investment,

Standard errors adjusted for cluster effects. 


\section{Conclusions}

This paper examines the impact of publicly backed venture capital funds in business innovation. In absence of other data (e.g. patent citations or proprietary company-level data on new product innovations/prototype development), we use patent applications as a proxy for innovation. We find that the statistically significant and negative coefficient observed between GVC backed investments and the firm's potential to innovate remains strong, even after controlling for a variety of factors associated with sectoral structures or investments characteristics: differences between regions, industry focus, investments size or investments stage. This suggests that this relationship is the result of some unmeasured investment characteristics or the environment in which funds operate. Such an unmeasured investment characteristic could be the chosen investment strategy of the GVCs funds. GVCs funds could have as part of their objectives to fill the gap associated with private funds giving priority to ventures engaged in patenting and tending to discount or even ignore ventures without patent activity. In this case public backed funds intentions might be in part to explicitly fill a gap that exists because private funds require (or give strong preference) to ventures engaged in patenting and ignore or underfund firms that have yet to patent or apply for a patent. Under this scenario, we would expect that GVCs funds would tend to be more interested in "pre or non-patenting" firms than private firms and would tend to pull out of investments when patent applications are made, leaving those investments to the private venture capital funds. In this case, the empirical results of this research may be an outcome of the ex-ante policy choices made by publicly backed fund managers (e.g. to invest in very early stage companies which are neglected by private funds). However, our analysis also shows that when selecting companies for a first round investment, patents are equally important (or unimportant) to both GVCs and PVCs.

Another explanation of the results is that venture capitalists from the publicly backed funds included in our sample may not have the skills required for nurturing high growth ventures. While they were able to identify companies with innovation potential, perhaps due to their extended network of contacts with the regional innovation ecosystem (including universities and science parks) they were less capable of nurturing these companies after they included them in their fund portfolio.

Our analysis has few limitations that we acknowledge. First, our paper does not deal with the causality, which is due to data limitations, and we observe an association only 
between patent application and source of funding. Second, the quality of the patents has not been accessed. Patents backed by publicly backed funds may be of better quality of those backed by private funds or the opposite. Lerner et al. (2008) research on patent quality (using number of citations as a proxy for economic importance) found that patents applied by firms in private equity transactions are more cited, and such research could be undertaken within the framework of a follow up study. Third, patents have been used as a proxy for innovation. Although the literature accepts that patent creation is an important measurement for innovation, additional proxies for innovation could be used in future analysis such as licenses, trademarks, number of new products in the market, copyrights etc. One may argue, for example, that patents have more to do with intellectual property protection of innovations and not necessarily capture innovation itself. Forth, additional dependent variables could be used in future analysis such as the performance of the VC backed companies and its association with patent and public or private investment. In this sense, performance could be defined as company turnover, employment growth etc. Fifth, our dataset does not include information on exited firms and therefore we were not able to test the potential influence of survivorship bias. Finally, a further research could control for other characteristics of the firm that may affect its innovation outputs, such as size of firm, foreign ownership, export activity, openness, structure and R\&D activity among others. 


\section{References}

Arqué-Castells, P. (2012). How venture capitalists spur invention in Spain: evidence from patent trajectories, Research Policy, 41, 897-912.

Amuedo-Dorantes, C. and Kimmel, J. (2005). Moonlighting Behavior over the Business Cycle, Discussion Paper Series, Institute for the Study of Labor, IZA DP No. 1671.

Baum, J., and B., Silverman (2004). Picking winners or building them? Alliance, intellectual and human capital as selection criteria in venture financing and performance of biotechnology startups, Journal of Business Venturing, 19, 2004, 411-436.

Brander, J., D., Qianqian, and T., Hellmann (2014). The Effects of Government-Sponsored Venture Capital: International Evidence. Review of Finance, doi:10.1093/rof/rfu009.

Buzzachi, L., Scellato, G., and E., Ughetto. (2013). The Investment strategies of publicly sponsored venture capital funds, Journal of Banking \& Finance, 37, 707-716.

Bygrave, W. B., and Timmons, J. A. (1992). Venture Capital at the Crossroads, Boston: Harvard Business School Press.

Cameron, A. C. and Trivedi, P. K. (1998). Regression Analysis of Count Data, New York: Cambridge Press.

Cappellari, L. and Jenkins, S. (2003). Multivariate probit regression using simulated maximum likelihood, Stata Journal, 3(3), 278-294.

Chung, W., \& Yeaple, S. (2008). International knowledge sourcing: Evidence from US firms expanding abroad. Strategic Management Journal, 29, 1207-1224.

Frenz, M. and Oughton, C. (2005). Innovation in the UK Regions and Devolved Administration: A Review of the Literature, Final report for the Department of Trade and Industry and the Office of the Deputy Prime Minister, London, June 2005.

Gompers P., and Lerner, J. (2001). The venture capital revolution. Journal of Economic Perspectives, 15(2), 145-168.

Gompers, P. and Lerner, J. (1999). The Venture Capital Cycle. Cambridge: MIT Press.

Gompers, P. (1995), Optimal Investment, Monitoring, and the Staging of Venture Capital," Journal of Finance, 50, 1461-1489.

Gorman, M. and Sahlman A.W. (1989). What do venture capitalists do?, Journal of Business Venturing, 4, 231-248. 
Greene, W. H. (2003). Econometric Analysis, $5^{\text {th }}$ Edition, Upper Saddle River, NJ. Prentice Hall.

Griliches, Z. (1998). Patent Statistics as Economic Indicators: A Survey, NBER, 287 - 343.

Haeussler C., D. Harho and E. Mueller. (2009). To Be Financed or Not. The Role of Patents for Venture Capital Financing, CEPR Discussion Papers 7115.

Hall, B.H., Jaffe, A.B. and Tratjenberg, M. (2001). The NBER Patent Citation Data File: Lessons, Insights and Methodological Tools, NBER Working Paper 8498.

Hall, B.H., Lerner, J., (2010). The financing of R\&D and innovation. In: Hall, B.H.,Rosenberg, N. (Eds.), Handbook of the Economics of Innovation. Elsevier, Amsterdam, 610-638.

Harris, M. N. \& Rogers, M. \&Siouclis, A. (2001). Modelling Firm Innovation Using Panel Probit Estimators. Melbourne Institute Working paper, No 20/01, University of Melbourne, Melbourne, Australia.

Harrison R. T., and Mason C, M., (2000). Venture capital market complementarities: The links between business angels and venture capital funds in the United Kingdom, Venture Capital, 2(3), 223-242.

Heckman, J. (1979). Sample selection bias as a specification error, Econometrica, 47, 153161.

Hellman, T., and Puri M., (2002). Venture capital and the professionalisation of start-ups: Empirical Evidence, Journal of Finance, 57, 169-197.

Hellmann, T., and Puri, M., (2000). The interaction between product market and financing strategy: The role of venture capital, Review of Financial Studies, 13(4), 959-984.

Hirukawa and Ueda (2011). Venture Capital and Innovation: Which is First?, Pacific Economic Review, 16(4), 421-465.

Hochberg, Y., A. Ljungqvist, and Lu, Y., (2007). Whom You Know Matters: Venture Capital Networks and Investment Performance, Journal of Finance, 62, 251-301.

Hoskisson, R.E., Hitt, M.A., Johnson, R.A., Grossman, W., (2002). Conflicting voices:the effects of institutional ownership heterogeneity and internal governance on corporate innovation strategies, Academy of Management Journal, 45 (4), 697-716.

Jaffe and Lerner (2004). Into the Patent Thicket. Princeton NJ: Princeton University Press. 
Johnson S, Webber D j and Thomas W. (2007). Which SMEs use external business advice? A multivariate sub-regional study, Environment and Planning A, 39(8), 1981-1997.

Kanniainen, V. and Keuschnigg, C. (2004). Start-up investment with scarce venture capital support, Journal of Banking and Finance, 28, 1935-1959.

Kaplan, S. N., Sensoy, B. A., and Stromberg, P. (2009). Should investors bet on the jockey or the horse? Evidence from the evolution of firms from early business plans to public companies, Journal of Finance, 64(1), 75-115.

Kaplan, S., N., and Stromberg, P. (2001). Financial contracting meets the real world: an empirical analysis of venture capital contracts', Review of Economic Studies, 1-35.

Knockaert, M., Lockett, A., Clarysse, B., Wright, M. (2006). Do human capital and fund characteristics drive follow-up behaviour of early stage high-tech VCs?, International Journal of Technology Management, 34, 7-27.

Kortum, S. \& Lerner, J. (2000). Assessing the contribution of venture capital to innovation, RAND Journal of Economics, 31(4), pp. 674-692.

Lerner, J and Watson, B. (2008). The public venture capital challenge: the Australian case, Venture Capital: an international journal of entrepreneurial finance, 10, 1-20.

Lerner, J. (2002). When bureaucrats meet entrepreneurs: The design of effective "public venturecapital'” programmes, Economic Journal, 112(477), F73-F84.

Lerner, J., Sørensen, M., and Strömberg, P. (2008). Private Equity and Long-Run Investment: The Case of Innovation, NBER Working Paper No. 14623.

Luukkonen, T., Deschryvere, M., Bertoni, F., Nikulainen, T. (2013). The value added by government venture capital funds compared with independent venture capital funds, Technovation 33 (4-5), 154-162.

Mann, J. R. and Sager ,W. T. (2007). Patents, venture capital, and software start-ups, Research Policy, 36, pp. 193-208.

Martin, R, P. Sunley, P and Turner, D. (2002). Taking risks in regions: the geographical anatomy of Europe's emerging venture capital market', Journal of Economic Geography, 2 (2), p. 121-150.

Mason C. and Pierrakis Y. (2011). Venture capital, the regions and public policy: the United Kingdom since the post-2000 technology crash, Regional Studies. DOI: 10.1080/00343404.2011.588203 
Mason, C. M., and Harrison, R. T. (2008). Measuring business angel investment activity in the United Kingdom: a review of potential data sources, Venture Capital: an international journal of entrepreneurial finance, 10, 309-330.

Mason, C., and Harrison, R. (1999). Financing entrepreneurship: venture capital and regional development in, Martin R ed Money and the space economy Wiley, New York, 157-83.

Mason, C., and Harrison, R. (2002). The geography of venture capital investments in the UK, Royal Geographical Society (with the Institute of British Geographers).

Mason, C., and Harrison, R. (2003). Closing the Regional Equity Gap? A Critique of the Department of Trade and Industry's Regional Venture Capital Funds Initiative, Regional Studies, 37(8), p. 855-868.

Munari, F., and Toschi, L. (2010). Assessing the impact of public venture capital programmes in the UK: do regional characteristics matter?, Department of Management, UniversitàdegliStudi di Bologna.

NAO (2009). Venture Capital support to small business.

NESTA (2008). Stimulating Venture Capital, policy brief

NESTA (2009). Reshaping the UK economy, London

Nightingale P., Murray, G. , Cowling, M., Baden-Fuller, C., Mason, C., Siepel, J., Hopkins, M. and Dannreuther, C. (2009). From funding gaps to think markets: UK Government support for early-stage venture capital, NESTA.

Pinch, S., and Sunley, P. (2009). Understanding the Role of Venture Capitalists in Knowledge Dissemination in Technology Agglomerations: A Case Study of the University of Southampton Spin-Off Cluster, Venture Capital, 11(4), 311-333.

Popov, A.A., Roosenboom, P. (2012). Venture capital and patented innovation: evidence from Europe, Economic Policy, 27 (71), 447-482.

Schäfer and Schilder, D. (2009). Smart capital in German start-ups: an empirical analysis, Venture Capital: an international journal of entrepreneurial finance, 11(2), 163-183.

Smith, J., (2005). Empirical study of a venture capital relationship, Accounting, Auditing \& Accountability Journal, 18(6), 756 -783.

Sorenson O., and Stuart, T. (2001). Syndication Networks and the Spatial Distribution of Venture Capital Investments1ucsd.edu - ajs, 2001 - University of Chicago Press.

Sunley, P., Klagge, B., Berndit, C., and Ron, M. (2005).Venture capital programmes in the UK and Germany: In what sense regional policies?, Regional Studies, 39(2), 255-273. 
Timmons A. J. and Spinelli, S. (2003). New Venture Creation, Entrepreneurship for the 21st Century, New York: McGraw-Hill.

Ueda M., Hirukawa M. (2006). Venture Capital and Industrial Innovation, Working Paper, May 200

Verdolini, E., and M., Galeotti. (2009). At Home and Abroad: An Empirical Analysis of Innovation and Diffusionin Energy-Efficient Technologies. Working Paper n. 26 November 2009, IEFE - The Center for Research on Energy and Environmental Economics and Policy at Bocconi University.

Zhang, J. (2007). Access to venture capital and the performance of venture capital-backed star-ups in Silicon Valley, Economic Development Quarterly, 21, 124-147. 


\section{Appendix}

Table A1: Description of variables

\begin{tabular}{|c|c|c|}
\hline Variable & Description & Source \\
\hline Patents & $\begin{array}{l}\text { The number of patent application at the time of investment } \\
\text { (categorical variable) }\end{array}$ & EPO \\
\hline $\begin{array}{l}\text { Had a patent when } \\
\text { received its } 1 \mathrm{st} \\
\text { investment }\end{array}$ & $\begin{array}{l}\text { Dummy that takes the value } 1 \text { if the company had applied for one, } \\
\text { and } 0 \text { otherwise }\end{array}$ & EPO \\
\hline $\begin{array}{l}\text { There was an increase in } \\
\text { patents since } 1 \text { st } \\
\text { investment }\end{array}$ & $\begin{array}{l}\text { Dummy that takes the value } 1 \text { if the company applied for one or } \\
\text { more patents, and } 0 \text { otherwise }\end{array}$ & EPO \\
\hline PVCs & $\begin{array}{l}\text { Dummy that takes the value } 1 \text { if the deal is made solely by one or } \\
\text { more private funds }\end{array}$ & $\begin{array}{l}\text { Library } \\
\text { House, desk } \\
\text { research }\end{array}$ \\
\hline GVCs & $\begin{array}{l}\text { Dummy that takes the value } 1 \text { if the deal is made solely by one or } \\
\text { more publicly backed funds }\end{array}$ & $\begin{array}{l}\text { Library } \\
\text { House, desk } \\
\text { research }\end{array}$ \\
\hline $\begin{array}{l}\text { GVCs + PVCs Co- } \\
\text { investments }\end{array}$ & $\begin{array}{l}\text { Dummy that takes the value } 1 \text { if the deal is a syndicate between a } \\
\text { publicly backed fund and a private fund }\end{array}$ & $\begin{array}{l}\text { Library } \\
\text { House, desk } \\
\text { research }\end{array}$ \\
\hline Deal size & A measurement of the size of the deal in square root & Library House \\
\hline Number of round & $\begin{array}{l}\text { An ordinal variable indicating the number of funding round when } \\
\text { the deal took place }(1-8)\end{array}$ & Library House \\
\hline Regional dummies & $\begin{array}{l}\text { Dummies that take the value } 1 \text { if the company that received the } \\
\text { investment is located in a particular region and } 0 \text { otherwise }\end{array}$ & Library House \\
\hline Industry dummies & $\begin{array}{l}\text { Dummies that take the value } 1 \text { if the company that received the } \\
\text { investment operates in a particular region, and } 0 \text { otherwise }\end{array}$ & Library House \\
\hline Year dummies & $\begin{array}{l}\text { Dummies that take the value if the investment took place in a } \\
\text { particular year and } 0 \text { otherwise }\end{array}$ & Library House \\
\hline
\end{tabular}


Table A2: Mean difference test results for Table 3

\begin{tabular}{ccccccccc}
\hline \multicolumn{2}{c}{ PVCs- GVCs \& PVCs Co-investments } & \multicolumn{3}{c}{ PVCs - GVCs } & \multicolumn{3}{c}{ GVCs - GVCs \& PVCs Co- } \\
investments
\end{tabular}

